\title{
Effect of thalidomide on the healing of colonic anastomosis, in rats ${ }^{1}$
}

\author{
Efeito da talidomida na cicatrização de anastomoses colônicas em ratos
}

\author{
Samuel Gama Veneziano ${ }^{\mathrm{I}}$, Leandra Naira Zambelli Ramalho ${ }^{\mathrm{II}}$, Fernando Silva Ramalho ${ }^{\mathrm{III}}$, Antônio Dorival Campos ${ }^{\mathrm{IV}}$, \\ José Joaquim Ribeiro da Rochav , Omar Feres ${ }^{\mathrm{VI}}$ \\ I Fellow Master degree, Division of Coloproctology, Department of Surgery and Anatomy, Ribeirão Preto Faculty of Medicine, University \\ of São Paulo, Brazil. \\ II PhD, Professor, Department of Pathology, Ribeirão Preto Faculty of Medicine, University of São Paulo, Brazil. \\ III PhD, Professor, Department of Surgery and Anatomy, Ribeirão Preto Faculty of Medicine, University of São Paulo, Brazil. \\ ${ }^{\text {IV }} \mathrm{PhD}$, Professor, Department of Social Medicine, Ribeirão Preto Faculty of Medicine, University of São Paulo, Brazil. \\ v PhD, Professor, Division of Coloproctology, Department of Surgery and Anatomy, Ribeirão Preto Faculty of Medicine, University of São \\ Paulo, Brazil. \\ vi PhD, Professor, Division of Coloproctology, Department of Surgery and Anatomy, Ribeirão Preto Faculty of Medicine, University of \\ São Paulo, Brazil.
}

\begin{abstract}
Purpose: Thalidomide, because of its anti-inflammatory properties, as re-emerged as an option for the treatment of Crohn's disease refractory to standard therapy. We studied the effect of thalidomide on the healing of colonic anastomosis. Methods: Sixty male rats (Rattus norvegicus), were divided into 3 groups of 20 animals each, respectively receiving 0.5 or $1.0 \mathrm{mg} / \mathrm{kg}$ thalidomide by the oral route for 7 days, or saline solution (control). All animals were submitted to continuous end-to-end anastomosis with 6-0 Prolene sutures. After sacrifice the anastomoses were analyzed macroscopically and submitted to determination of hydroxyproline, to histology and to immunohistochemistry for metalloproteinase 1, metalloproteinase 1 inhibitor and vascular endothelial growth factor (VEGF). Results: Statistical analysis of the data showed no significant difference in macroscopic aspect or hydroxyproline determination $(p=0.5403)$. In the immunohistochemical analysis, the following $p$ values were obtained: $p=0.5817$ for VEGF, $\mathrm{p}=0.1854$ for metalloproteinase 1 , and $p=0.0023$ for metalloproteinase 1 inhibitor, with this last value being considered statistically significant. Conclusion: We conclude that thalidomide influenced collagen maturation. There was a stronger action of metalloproteinases, possibly indicating a negative tendency for the healing process.
\end{abstract}

Key words: Thalidomide. Colonic Anastomosis. Healing. Anastomosis Leakage. Crohn's Disease

\section{RESUMO}

Objetivo: Sabe-se que agentes farmacológicos podem influenciar no processo de cicatrização. A talidomida, devido às suas propriedades antiinflamatórias, tem ressurgido como uma opção no tratamento da doença de Cröhn refratária à terapêutica convencional. Neste trabalho, estudamos o efeito da talidomida na cicatrização de anastomoses colônicas no rato. Métodos: Foram utilizados 60 animais Rattus norvegius, com peso médio de $300 \mathrm{~g}$. Organizou-se 3 grupos de 20 animais, sendo um grupo controle (AC), um grupo (BD), com administração de talidomida $0,5 \mathrm{mg} / \mathrm{kg}$ por 7 dias e um grupo (AD) com administração de talidomida $1,0 \mathrm{mg} / \mathrm{kg}$ por 7 dias. Foi realizada anastomose término-terminal contínua de prolene 6-0. O sacrifício foi no $7^{\mathrm{o}}$. dia pós operatório e as anastomoses foram analisadas quanto a aspecto macroscópico, dosagem de hidroxiprolina, histologia em hematoxilina-eosina e imuno-histoquímica para metaloproteinase 1, inibidor de metaloproteinase 1 e VEGF. Resultados: Não houve diferença estatisticamente significante para a observação macroscópica e para dosagem de hidroxiprolina $(\mathrm{p}=0,5403)$. Na análise imunohistoquímica, para VEGF houve $p=0,5817$, para metaloproteinase $1, p=0,1854$ e para inibidor de metaloproteinase, $p=0,0023$, considerado estatisticamente significante. Conclusão: Concluímos que a talidomida influenciou na maturação do colágeno. Notou-se maior ação das metaloproteinases, que pode significar uma tendência negativa para o processo cicatricial.

Descritores: Talidomida. Anastomose Cirúrgica. Cólon. Cicatrização de Feridas. Deiscência de Ferida Operatória. Doença de Crohn.

1. Study performed in the Division of Coloproctology of the Department of Surgery and Anatomy of Ribeirão Preto Faculty of Medicine,

University of São Paulo, Brazil. 


\section{Introduction}

The healing process in general and the healing of digestive anastomosis in particular has been the subject of exhaustive studies and has long raised heated debate in the history of Surgery. The healing of anastomosis is of fundamental importance for the favorable results that all surgeons expect for their patients and its failure, with dehiscence, is one of the main causes of complications in surgeries of the intestinal tract since dehiscence is accompanied by high morbidity and mortality due to (para deixar fecal deveria descrever como cirurgia no colon e não no trato intestinal como um todo-sugiro deixar somente: peritonitis) peritonitis and sepsis. ${ }^{1-5}$

Healing is a complex process depending on multiple intrinsic and extrinsic factors for successful completion. The healing of anastomosis is influenced by the general condition of the patient, ${ }^{6}$ the blood supply and oxygenation of tissue, ${ }^{7}$ the quality of the local vascular network, ${ }^{8}$ oxygen tension, ${ }^{9}$ tension along the anastomosis line, ${ }^{10}$ blood volume, ${ }^{11}$ peritoneal infection, ${ }^{12}$ sepsis,${ }^{13}$ vitamin deficiency, ${ }^{14}$ surgical technique, ${ }^{15}$ surgeon experience, ${ }^{6}$ as well as the nature of the surgical intervention and the site of the anastomosis, whether extra- or intraperitoneal. ${ }^{6}$ Other influencing factors are blood transfusions, ${ }^{16}$ radiotherapy, ${ }^{17}$ blood viscosity, ${ }^{18}$ presence of drains close to the anastomosis, ${ }^{19}$ patient age,${ }^{20}$ clinical nutritional situation, ${ }^{2}$ dehydration, ${ }^{21}$ uremia, ${ }^{22}$ and mechanical intestinal preparation, ${ }^{23}$ use of antibiotic prophylaxis in colorectal surgeries, ${ }^{24}$ diabetes mellitus, ${ }^{5}$ obstructive jaundice, ${ }^{25}$ and surgical adhesives, ${ }^{26}$ among other clinical conditions .

The use of pharmacological agents can affect healing, as previously demonstrated by several authors using corticosteroids, ${ }^{27}$ pentoxifylline,${ }^{28}$ antineoplastic drugs, ${ }^{29}$ and non-hormonal anti-inflammatories. ${ }^{30}$ Regarding drugs, thalidomide, although banned several decades back due to its teratogenic effects, has been pointed out in recent papers as beneficial for the treatment of Crohn's disease resistant to corticotherapy and of difficult clinical management with conventional drugs. ${ }^{31,32}$ Thalidomide has an important immunomodulatory action, inhibiting the action of tumor necrosis factor (TNF) and having anti-angiogenic activity, among others. ${ }^{33}$

In view of the difficult clinical management of Crohn's disease refractory to traditional treatment, and considering the biochemical actions of thalidomide and the good results obtained with it by some authors in controlled studies, this drug may gain a place in the therapeutic arsenal in the near future. Parallel to the possible routine use of the drug, in some situations surgeries with colonic anastomosis must be performed in patients with Crohn's disease in the presence of long-lasting therapy. This motivated us to test the influence of thalidomide on the healing of colonic anastomoses in rats.

\section{Methods}

The study was approved by the Ethics Committee on Animal Experimentation of the Faculty of Medicine of Ribeirão Preto, University of São Paulo (protocol no. 035/
2005). All procedures were performed in accordance with the ethical standards laid down in the 1964 Declaration of Helsinki. Sixty healthy male Wistar rats (Rattus norvegicus) aged 60 to 80 days and weighing about $300 \mathrm{~g}$ were used for the study. The animals were kept in appropriate animal facilities under controlled conditions throughout the experiment, with free access to standard laboratory chow and water.

The animals were divided at random into three groups: Group CA (control animals), consisting of 20 rats receiving a daily dose of $0.5 \mathrm{ml} 0.9 \%$ saline solution by gavage for 7 days. Group LD (a low dose of thalidomide) consisting of 20 rats receiving by gavage a daily dose of $0.5 \mathrm{mg} / \mathrm{kg}$ thalidomide diluted in $0.5 \mathrm{ml}$ saline solution for 7 days, and Group HD (a high dose of thalidomide) receiving by gavage a daily dose of $1.0 \mathrm{mg} / \mathrm{kg}$ thalidomide diluted in $0.5 \mathrm{ml}$ saline solution for 7 days.

On the eighth day, the animals were operated upon. After general anesthesia _(apesar de todos nós usarmos o éter para anesthesia, em revistas internacionais, já recebi várias críticas por não ter utilizado anesthesia com agente endovenoso ou intramuscular no lugar do éter), the animals were submitted to median laparotomy and to colotomy of a left colon segment of 2.5 to $3.5 \mathrm{~cm}$ proximal to the peritoneal reflexion. Transit was then reconstituted by means of a continuous end-to-end anastomosis on the total posterior plane and on the invaginating seromuscular anterior plane with 6-0 polypropylene sutures and a $1.3 \mathrm{~cm}$ cylindrical needle (Prolene® - Etichon), followed by plane by plane suture of the cavity.

During the postoperative period, the solutions were again administered daily by gavage until sacrifice on the 7 th postoperative day. The animals were sacrificed and a wide median thoracolaparotomy was performed, with full exposure of the abdomen. The cavity was inspected and the macroscopic aspect of the colonic anastomosis was examined, with recording of epiploon adhesions, presence of peritonitis or abscesses, and presence of macroscopic dehiscence. After this examination, a segment of distal colon of about $2 \mathrm{~cm}$ containing the anastomosis in its central portion was resected. The segment was isolated, cleaned with saline solution, opened longitudinally in the mesenteric portion, and again cleaned with saline solution.

The fragment was then divided into two portions: $1 / 4$ of the anastomosis was placed in ice-cold $0.9 \%$ formalin and immediately sent to the laboratory where it was frozen at $-20^{\circ} \mathrm{C}$ for later determination of hydroxyproline. The remaining $3 / 4$ of the segment was fixed on cardboard, immersed in 10\% buffered formalin and used for histopathology and immunohistochemistry.

The following parameters were used to analyze the healing process of the anastomosis: 1) macroscopic aspect of the abdominal cavity and of the colonic anastomosis; 2) biochemical study with the determination of hydroxyproline along the anastomosis line, ${ }^{34,35} 3$ ) histopathological evaluation (hematoxylin-eosin) with 
analysis of the following indicators. ${ }^{36,37}$ fibrin-leukocyte crust, focal necrosis, fibrin deposits, neutrophil exudate, edema, lymphatic dilatation, vascular congestion, focal hemorrhage, mucosal regeneration, macrophage infiltration, granulomas, vascular neoformation, fibroblast proliferation, and fibrosis. Each indicator was scored as: $(0)=$ absent, $(+)$ $=$ mild, $(2+)=$ moderate, and $(3+)=$ intense. 4$)$ Immunohistochemical evaluation for the detection of markers of metalloproteinase type I (MMP1), MMP1 inhibitor (MMP1I), and vascular endothelial growth factor (VEGF). The mean values for fields stained for each marker were computed.

\section{Statistical analysis}

Data regarding the macroscopic analysis of the anastomoses were analyzed statistically by the Fisher exact test and by the riddit-score test ${ }^{38}$ and data regarding hydroxyproline determination were analyzed by the KruskalWallis test (nonparametric ANOVA). The qualitative data obtained by analysis of the sections stained with hematoxylin-eosin were analyzed using the riddit-scores. The immunohistochemical data for MMP1, MMP1I and VEGF were analyzed by the Kruskal-Wallis test. The level of significance was set at $p<0.05$ for all analyses.

\section{Results}

The data concerning the macroscopic aspect of the anastomosis are listed in Table 1. There were no statistically significant differences between groups. The riddit-score was 0.08 for the absence of adhesions, 0.49 for fine adhesions and 0.90 for gross adhesions, with no difference between groups.

The quantitative analysis of hydroxyproline concentration revealed that the groups did not differ significantly $(p=0.5403)$. Semi-quantitative analysis of histological sections stained with hematoxylin-eosin regarding the parameters listed in table 2 revealed significant differences between groups for fibrin-leukocyte crust, hemorrhage, vascular neoformation and fibrosis. The significance values are given in the table.

TABLE 1 - Macroscopic data observed in the various groups after sacrifice on the 7th postoperative day

\begin{tabular}{|c|c|c|c|}
\hline Anastomosis & Control animals & $\begin{array}{c}\text { Animals treated with a } \\
\text { low thalidomide dose } \\
(0.5 \mathrm{mg} / \mathrm{kg})\end{array}$ & $\begin{array}{l}\text { Animals treated with a } \\
\text { high thalidomide dose } \\
(1.0 \mathrm{mg} / \mathrm{kg})\end{array}$ \\
\hline Intact & 18 & 19 & 17 \\
\hline Dehiscent & 2 & 1 & 3 \\
\hline \multicolumn{4}{|c|}{$P=0.863$ (no statistically significant difference between groups) } \\
\hline \multicolumn{4}{|c|}{ Peritonitis } \\
\hline Yes & 0 & 1 & 1 \\
\hline No & 20 & 19 & 19 \\
\hline \multicolumn{4}{|c|}{$P=1.000$ (no statistically significant difference between groups) } \\
\hline \multicolumn{4}{|c|}{ Adhesions } \\
\hline Absent & 1 & 3 & 6 \\
\hline Fine & 15 & 13 & 11 \\
\hline Gross & 4 & 4 & 3 \\
\hline
\end{tabular}

TABLE 2 - Statistical comparison of the groups studied (control, C; low thalidomide dose of $0.5 \mathrm{mg} / \mathrm{kg}, \mathrm{LD}$; and high thalidomide dose of $1.0 \mathrm{mg} / \mathrm{kg}$, HD) regarding various anastomosis parameters determined after surgery.

\begin{tabular}{lccc}
\hline Parameter & C-LD Comparison & C-HD Comparison & LD-HD Comparison \\
\hline Fibrin-leukocyte crust & $p=0.7264$ & $p=0.0006^{*}$ & $p=0.0020^{*}$ \\
Necrosis & $p=0.3222$ & $p=0.2938$ & $p=0.0414^{*}$ \\
Edema & $p=0.0016^{*}$ & $p=0.8492$ & $p=0.0008^{*}$ \\
Hemorrhage & $p=0.0074^{*}$ & $p=0.4412$ & $p=0.0562$ \\
Vascular neoformation & $p=0.0376^{*}$ & $p=1.0000$ & $p=0.0376^{*}$ \\
Fibrosis & $p=0.0082^{*}$ & $p=0.2670$ & $p=0.1236$ \\
\hline * Statistically significant difference & & &
\end{tabular}

* Statistically significant difference 
The mean results of immunohistochemical analysis of stained fields showed non significant differences between groups for the VEGF marker $(p=0.5817)$ and for MMP1I ( $p$ $=0.1854)$. Regarding MMP1, there was a highly significant difference between groups $(p=0.0023)$. The multiple comparison test of Muller showed statistically significant differences between the control group and the low thalidomide dose $(0.5 \mathrm{mg} / \mathrm{kg})$ group and between the low thalidomide dose group and the high thalidomide dose group $(1.0 \mathrm{mg} / \mathrm{kg})$, as shown graphically in Figure 1.

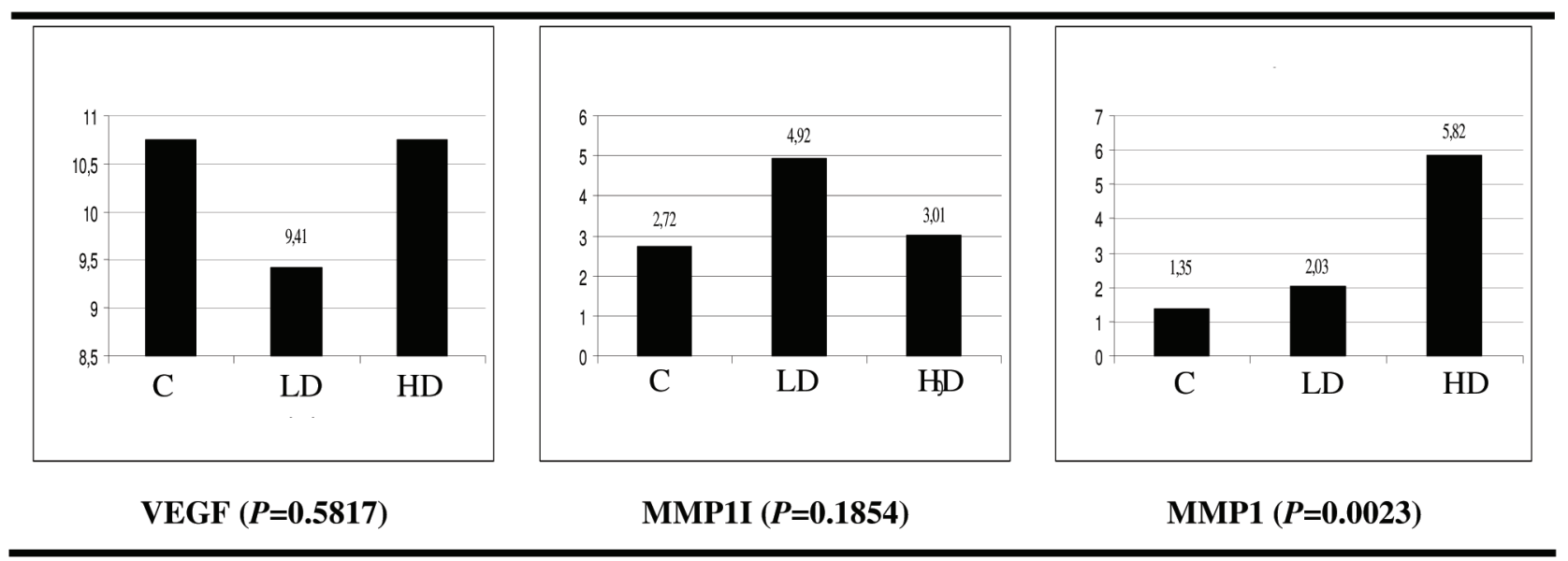

FIGURE 1 - Comparison of the groups studied regarding vascular endothelial growth factor (VEGF), marker of metalloproteinase 1 inhibitor (MMP1I) and marker of metalloproteinase1 (MMP1). $\mathrm{C}=$ control group; $\mathrm{LD}=$ low thalidomide dose group $(0.5 \mathrm{mg} / \mathrm{kg}) ; \mathrm{HD}=$ high thalidomide dose group $(1.0 \mathrm{mg} / \mathrm{kg})$.

\section{Discussion}

Healing is a complex process mediated by multiple factors which culminates in organized collagen synthesis. The objective of the present study was to investigate how thalidomide, a drug which could potentially be used in the future for the control of Crohn's disease refractory to classical treatment, interferes with the process of colonic healing since many patients with this disease require intestinal surgery during some phase of treatment.

The healing process of intestinal anastomosis involves complex biochemical and cellular steps, with collagen synthesis being of fundamental importance. The basic mechanisms involved in the healing process are: aggression, inflammation, collagen metabolism, epithelialization, and wound contraction. After aggression, which in the present study consisted of a colonic anastomosis, the first stage involves mechanisms of vasoconstriction and coagulation, with the formation of a thrombus and local platelet activation. The activated platelets release cytokines such as platelet-derived growth factor (PDGF), corresponding to the primordial stimulus for cell chemotaxis, transforming growth factor beta (TGFb), platelet activating factor (PAF), fibronectin, and serotonin. PAF stimulates the arrival of fibroblasts as well as polymorphonuclear cells, mast cells and macrophages, which complement the inflammatory reaction. This equilibrated inflammation is fundamental for the occurrence of healing. The mediators dilate local capillaries, increasing vascular permeability, white cell diapedesis and macrophage and neutrophil taxis into the wound. The macrophages then promote phagocytosis of foreign matter, bacteria and clots, in addition to releasing their own cytokines. They also play a fundamental role in fibroblast activation and stimulation for collagen synthesis. ${ }^{39-41}$

On the second day after the execution of the anastomosis, the entire inflammatory process will promote accelerated collagen production at the site of the wound. During collagen deposition (with greater expression from the $4^{\text {th }}$ to the $12^{\text {th }}$ day) the formed collagen is concomitantly degraded by the action of metalloproteinases, with collagenase being the most important enzyme in this group. This enzymatic degradation occurs in an ordered manner to guarantee synthesis, adequate fiber intercrossing, removal of excess material, and modulation of healing. This collagen synthesis-lysis balance is finally regulated and guarantees correct healing. ${ }^{2}$ In addition to these lytic enzymes, an inhibitory group also participates, the so-called metalloproteinase inhibitors, which are fundamental to guarantee the correct modulation of the enzymatic system. These enzymes are significantly expressed only at sites that need healing, especially along the suture lines, and do not appear in other parts of the tissue outside the necessary site. $^{42}$

Using histochemical techniques, the presence of metalloproteinases is detected as early as during the first 24 hours of anastomosis healing, especially in the extracellular matrix of the mucosa. After 72 hours, they are still present in the mucosa but they are also detected in deeper layers, especially in fibrous tissues, where their remodeling lytic effect is needed. Their action continues while there is healing activity and is modulated by inhibitory enzymes. ${ }^{43}$ It has been already demonstrated that elevated submucosal collagen degradation by metalloproteinases can predispose to the dehiscence of anastomosis ${ }^{44}$ and that the 
inhibition of metalloproteinases can have a promising action in healing. ${ }^{45,46}$ Thus, a firmer scar is expected to occur in a tissue where the action of metalloproteinase inhibitors prevails, and a looser and more tenuous scar is expected to occur in situations of imbalance towards the presence of metalloproteinases (greater collagen degradation).

The concept of immunohistochemical analysis of VEGF also applies to the healing conditions, since greater and better collagen synthesis is expected in a tissue with an ample blood supply and with good vascular neoformation. Angiogenesis is a complex cellular phenomenon that leads to the formation of new capillaries by pre-existing endothelial cells. ${ }^{47}$ Cells such as macrophages, monocytes, lymphocytes, fibroblasts and endothelial cells can interfere with angiogenesis by releasing substances that promote or inhibit the process. In addition to VEGF, a potent mitogen exclusively acting on endothelial cells, ${ }^{48}$ other molecules are implicated in angiogenesis, such as fibroblast-derived growth factor (FGF), TGF- $\beta$ and PDGF. Thalidomide can inhibit the angiogenesis stimulated by the binding of VEGF to integrin $\alpha-v-\beta 5,{ }^{49}$ but the mechanism of this effect is unknown. ${ }^{50}$

\section{Macroscopic analyses of the anastomosis}

Macroscopic analysis of the animals' abdominal cavity at the time of sacrifice revealed a tendency to lower formation of adhesions or of more tenuous adhesions. Intracavity adhesions are the product of inflammation and of the response occurring after surgical trauma, in which TNF, IL-1, IL-4, IL-6 and IL-10 are involved..$^{51}$ A lower incidence of adhesions has been experimentally demonstrated in rabbits submitted to colonic anastomosis and intracavity thalidomide injection. ${ }^{52}$ The authors attributed their results to the known anti-TNF effects of thalidomide, which indirectly inhibits the formation of adhesions. There was no significant difference between groups regarding adhesions. However, when we analyzed the study population ( $\mathrm{n}=60$ animals) in terms of the probability of adhesions, comparison of the mean riddit for the various groups (control x low thalidomide dose, control $\mathrm{x}$ high thalidomide dose, and low $\mathrm{x}$ high thalidomide dose) showed that, even though the $P$ value was nonsignificant, the animals in the high thalidomide dose group had a higher probability of presenting a lower incidence of adhesions.

\section{Analysis of hydroxyproline concentration}

Overall analysis of collagen synthesis by the determination of hydroxyproline showed no statistically significant difference between groups. The drug did not affect gross collagen production but may have acted on the way this collagen is organized during its maturation.

\section{Histopathological analysis}

Histological analysis using hematoxylin-eosin revealed a significant difference in fibrosis, necrosis, fibrinleukocyte crust, edema, hemorrhage, and vascular neoformation vascular between the thalidomide-treated animals and the controls. There was less edema in the group treated with thalidomide. The literature has reported reduced vascular permeability after treatment with thalidomide, with a consequent reduction of edema, possibly due to an immunomodulatory effect of the drug, ${ }^{53}$ since lower vascular permeability implies lower chemotaxis of inflammatory cells in addition to lower edema.

In the treated animals there was a lower tendency to the formation of fibrosis at the site of anastomosis. Again, the immunomodulating effects of thalidomide leading to reduction of the inflammatory response may have influenced this lower formation of fibrosis, ${ }^{51}$ with the same mechanism being responsible for lower necrosis and a smaller fibrin-leukocyte crust in the treated animals.

In the control group there was a lower incidence of micro-hemorrhage. Thalidomide has been previously implicated in situations of teratogenesis explained by hemorrhagic processes..$^{54,55}$

We observed a higher tendency to the occurrence of vascular neoformation in the anastomoses of the animals treated with the drug. Thalidomide has been reported to have a well-documented anti-angiogenic effect. ${ }^{49,56}$ This finding may be due to the fact that vascular neoformation is a complex and little understood process, with other stimulating factors possibly having exceeded in vivo the inhibitory effects of the drug tested.

\section{Immunohistochemical coordination}

The results showed no significant difference between the 3 groups regarding the expression of VEGF at the level of the anastomosis, and histological analysis did not show a statistically significant difference between the high dose group and the control. There was better vascular neoformation in the low dose group (a small difference), suggesting that, if a possible anti-angiogenic effect occurred, it did not manifest as an action on this parameter and did not impair anastomosis healing regarding the parameters analyzed.

There was a high accumulation of metalloproteinases in the group treated with a high thalidomide dose compared to control and to the group treated with a low dose, but without corresponding higher rates of dehiscence. The drug probably induced fibroblasts and inflammation-mediating cells to synthesize more metalloproteinases, with some response regarding control with the inhibitors, although the concentrations of metalloproteinase inhibitors did not differ significantly between groups.

\section{Conclusion}

The present results show that thalidomide somehow affected collagen maturation, with the formation of anastomosis with less necrosis, less fibrosis, more remodeling, and a less pronounced fibrin-leukocyte crust. The drug had no significant effect on the action of VEGF and did not cause major damage to the vascularization of the anastomosis. We also noted a greater action of metalloproteinase, which may indicate a negative tendency regarding the healing process. 


\section{References}

01. Goligher JC, Graham NG, Dombal FT. Anastomotic dehiscence after anterior resection of rectum and sigmoid. Br J Surg. 1970;57:109-18.

02. Khoury GA, Waxman BP. Large bowel anastomos2s. The healing process and sutured anastomoses. A review. Br J Surg. 1983;70:61-3.

03. Ravo B. Colorectal anastomotic healing and intracolonic bypass procedure. Surg Clin North Am. 1988; 68:126794.

04. Mustoe TA, Landers A, Cromack DT, Mistry D, Griffin A, Deuel T F, Pierce G F. Differential acceleration of healing of surgical incision in the rabbit gastrointestinal tract by platelet-derived growth factor and transforming growth factor, type beta. Surgery. 1990;108:324-39.

05. Verhofstad MH, Lange WP, van der Laak JA, Verhofstad AA, Hendriks, T. Microscopic analysis of anastomotic healing in the intestine of normal and diabetic rats. Dis Colon Rectum. 2001;44:423-31.

06. Irvin TT, Goligher JC. Aetiology of disruption of intestinal anastomoses. Br J Surg. 1973;60:461-4.

07. Hunt TK, Zederfeldt B, Goldstick TK. Oxygen and healing. Am J Surg. 1969;118:521-5.

08. Schrock T, Cerra F, Hawley PR, Hunt TK, Nichols RL, Samson RB. Wounds and wound healing (clinical conference). Dis Colon Rectum. 1982;25:1-15.

09. Shandall A, Lowndes R, Young HL. Colonic anastomotic healing and oxygen tension. Br J Surg. 1985;72:606-9.

10. Getzen LC. Clinical use of everted intestinal anastomoses. Surg Gynecol Obstet. 1966;123:1027-36.

11. Carrico TJ, Mehrhof AI Jr, Cohen IK. Biology of wound healing. Surg Clin North Am. 1984;64:721-33.

12. Oliveira PG. Efeitos da Peritonite por Cândida Albicans na cicatrização de anastomoses colônicas: estudo experimental em ratos. Ribeirão Preto, 119p, 1995. Doctoral Thesis. Faculdade de Medicina de Ribeirão Preto, Universidade de São Paulo.

13. Ahrendt GM, Gardner K, Barbul A. Loss of colonic structural collagen impairs healing during intraabdominal sepsis. Arch Surg. 1994;129:1179-83.

14. Grillo HC, Gross J. Collagenolytic activity during mammalian wound repair. Dev Biol. 1967;15:300-7.

15. Halsted WS. Circular suture of the intestine: an experiment study. Am J Med Sci. 1887;75:436-61.

16. Schrock TR, Deveney CW, Dunphy JE. Factors contributing to leakage of colonic anastomoses. Ann Surg. 1973;177:513-8.

17. Orminston MC. A study of rat intestinal wound healing in the presence of radiation injury. Br J Surg. 1985;72:56-8.

18. Tagart RE. Colorectal anastomosis: factors influencing success. J R Soc Med. 1981;74:111-8.

19. Berliner SD, Bursonl LC, Learp PE. Intraperitoneal drains in surgery of the colon - Clinical evaluation of 454 cases. Am J Surg. 1967;113:646-7.

20. Irvint TT, Huntt TK. Effect of malnutrition on colonic healing. Ann Surg. 1994;180:765-71.
21. Hartmann M, Jönsson K, Zederfeldt B. Importance of dehydration in anastomotic and subcutaneous wound healing: an experimental study in rats. Eur J Surg. 1992;158:79-82.

22. Colin JF, Elliot P, Ellis H. The effect ou uraemia upon wound healing: an experimental study. Br J Surg. 1979;66:793-7.

23. Feres O, Monteiro dos Santos Jr C, Andrade JI. The role of mechanical bowel preparation for colonic resection and anastomosis: an experimental study. Int J Colorectal Dis. 2001;16:353-6.

24. Le Veenh H, Wapnick S, Falk G, Oliva SO, Bhat D, Guard REM, Pate LM. Effects of prophylactic antibiotics on colonic healing. Am J Surg. 1976;131:4753.

25. Sayan M, Alponat A, Yavuz N, Altinkaya E, Göksel S, Sariyar M. The effect of oral sodium taurocholate on endotoxemia and intestinal anastomotic wound healing in rats with obstructive jaundice. Surg Today. 1997;27:953-7.

26. van der Ham AC, Kort WJ, Weijma IM, van den Ingh HF, Jeekel H. Healing of ischemic colonic anastomosis: fibrin sealant does not improve wound healing. Dis Colon Rectum. 1992;35:884-91.

27. Sirimarco MT. Estudo comparativo dos efeitos de dois corticosteróides sintéticos, deflazacort e prednisona, na cicatrização de anastomoses colônicas de ratos Ribeirão Preto, 2000. 125p. Doctoral Thesis, Faculdade de Medicina de Ribeirão Preto, Universidade de São Paulo.

28. Cömert M, Taneri F, Tekin E, Ersoy E, Oktemer S, Onuk E, Düzgün E, Ayğlu F. The effect of pentoxifylline on the healing of intestinal anastomosis in rats. Surg Today. 2000;30:896-902.

29. Regazzini RCO. Efeitos do 5-fluoruracil na cicatrização de anastomoses colônicas: estudo experimental em ratos. Ribeirão Preto 1996. 66p. Master's Thesis, Faculdade de Medicina de Ribeirão Preto, Universidade de São Paulo.

30. Souza JB. Evolução da cicatrização de anastomoses colônicas sob a ação do diclofenaco sódico administrado no período perioperatório: estudo experimental em coelhos. Ribeirão Preto, 1994. 95p. Doctoral Thesis, Faculdade de Medicina de Ribeirão Preto, Universidade de São Paulo.

31. Wettstein AR, Meagher AP. Thalidomide in Crohn's disease. The Lancet. 1997;350:1445-6.

32. Vasiliauskas EA, Kam LY, Abreu-Martin MT, Hassard P, Papadakis KA, Yang H, Zeldis JB, Targan SR. An open-label pilot study of low-dose thalidomide in chronically active, steroid-dependent Crohn's disease. Gastroenterol. 1999;117:1278-87.

33. Braegger CP, Nicholls S, Murch SH, Stephens S, MacDonald TT. Tumour necrosis factor alpha in stool as a marker of intestinal inflammation. The Lancet. 1992;339:89-91.

34. Stegemann H, Stalder K. Determination of hydroxyproline. Clin Chim Acta. 1967;18:267-73.

35. Medugorac I. Collagen content in different areas of normal and hypertrophied rat myocardium. Cardiovasc Res. 1980;14:551-4. 
36. Oliveira PG. Estudo dos efeitos de uma prostaglandina sintética, o misoprostol, sobre a cicatrização de anastomoses no intestino grosso de ratos. Ribeirão Preto, 1989, 102 p. Master's Thesis, Faculdade de Medicina de Ribeirão Preto, Universidade de São Paulo.

37. Sousa JB. Efeitos da cicatrização de anastomoses no intestino delgado de coelhos tratados com diclofenaco sódico. Ribeirão Preto, 1989. 104p. Master's Thesis, Faculdade de Medicina de Ribeirão Preto, Universidade de São Paulo.

38. Fleiss JL. Statistical methods for rates and proportions $-2^{\text {nd }}$. Edition, Ed. John Wiley \& Sons, 1981.

39. Leibovich SJ, Ross R. A macrophage dependent factor that stimulates the proliferation of fibroblasts in vitro. Am J Pathol. 1976;84:501-7.

40. Casey WJ, Peacock EE, Chvapil M. Induction of collagen synthesis in rats by transplantation of allogenic macrophages. Surg Forum. 1976; 27:53-6.

41. Diegelmann RF, Cohen IK, Kaplan AM. The roles of macrophages in wound repair: a review. Plast Reconst Surg. 1981;68:107-3.

42. Chowcat NL, Savage FJ, Hembry RM, Boulos PB. Role of collagenase in colonic anastomoses - a reappraisal. Br J Surg. 1988;75:330-4.

43. Savage FJ, Lacombe DLP, Boulos PB, Hembry RM. Role of matrix metalloproteinases in healing of colonic anastomoses. Dis Colon and Rectum. 1997;40:962-7.

44. Syk I, Mirastschijski U, Jeppsson BW, Agren MS. Experimental colonic obstruction increases collagen degradation by matrix metalloproteinases in the bowel wall. Dis Colon Rectum. 2003;46:1251-9.

45. Jonsson T, Högström H. Neutrophil-dependent decrease in early wound margin strength. Arch Surg. 1991;126:1423-6.
46. Tani T, Tsutamoto Y, Eguchi Y, Araki H, Ebira Y, Ameno H, Fujino M, Oka H, Kodama M. Protease inhibitor reduces loss of tensile strength in rat anastomosis with peritonitis. J Surg Res. 2000;88:135-41.

47. Battegay EJ. Angiogenesis: mechanistic insights, neovascular diseases and therapeutic prospects. J Mol Med. 1995;73:333-46.

48. Folkman J, Shing I. Angiogenesis. J Biol Chem. 1992;267:10931-4.

49. Kruse FE, Joussen AM, Rohrscheneider K, Becker MD, Volker HE. Thalidomide inhibits corneal angiogenesis induced by vascular endothelial growth factor. Graef Arch Clin Exp Ophthalmol. 1998;236:4616.

50. D'Amato RJ, Loughnan MS, Flynn E, Folkman J. Thalidomide is an inhibitor of angiogenesis. Proc Natl Acad Sci USA. 1994;91:4082-5.

51. Chegini $\mathrm{N}$. The role of growth factors in peritoneal healing: transforming growth factor $\beta$ (TGF- $\beta$ ). Eur J Surg. 1997;577:17-23.

52. Mall JW, Schwenk W, Philipp AW, Müller JM, Pollmann C. Thalidomide given intraperitoneally reduces the number of postoperative adhesions after large bowel resection in rabbits. Eur J Surg. 2002;168:641-5.

53. Miller JM, Ginsberb M, Mc Elfatrick GC, Shonberg IL. The anti-inflammatory effect and the analgesic property of thalidomide. Antibiot Med Clin Ther. 1960;7:743-6.

54. Persuad TN, Moore KL. Causes and prenatal diagnosis of congenital abnormalities. J Obst Gynecol Nursing. 1974;3:40-7.

55. Poswillo D. Hemorrhage in development of the face. Birth Defects Orig Artic Ser. 1975;11:61-81.

56. Kenyon BM, Browne F, D'Amato RJ. Effects of thalidomide and related metabolites in a mouse corneal model of neovascularization. Exp Eye Res. 1997;64:9718.

\title{
Correspondence:
}

Omar Féres

Department of Surgery and Anatomy

Ribeirão Preto Faculty of Medicine, University of São Paulo

14.048-900 Ribeirão Preto, São Paulo, Brazil.

Conflite of interest: no oferes@fmrp.usp.br

\section{How to cite this article:}

Veneziano SG, Ramalho FS, Campos AD, Rocha JJR, Feres O: Effect of thalidomide on the healing of colonic anastomoses. An experimental study on rats. Acta Cir Bras [serial on the Internet], 2008; 23 Suppl 1. Available from URL: http://www.scielo.br/acb.

\begin{abstract}
Comments:
Most patients with Crohn's disease ultimately require one or more operations over their lifetime (78\% and $90 \%$ after 20 and 30 years). Even with the availability of various immunosuppressive therapies such as azathioprine, mercaptopurine, and methotrexate, the treatment of patients with Crohn's disease (CD) refractory to steroids still remains a clinical challenge. TNF- $\alpha$ is considered to be centrally involved in the inflammatory process in CD. Thalidomide, developed in the 1950 s as a sedative but subsequently withdrawn from widespread use in the 1960s because of teratogenicity, is an agent with TNF$\alpha$ suppressive property. Was introduced into the therapy of CD by Wettstein and Meagher. In this context, there is a real concern that thalidomide can affect the healing of colonic anastomosis in such patients, what makes this study a very important one. As showed by the authors in a rat model, although thalidomide didn't affect the concentration of hydroxyproline on colonic anastomosis, the collagen maturation was altered, causing some histopathological changes between groups. Was also observed that the drug promoted greater action of metalloproteinase, what could lead to a higher rate of dehiscence, a fact that didn't happen at all. More studies must be stimulated on this subject.
\end{abstract}

\section{Wilson Salgado Júnior}

MD, PhD, Department of Surgery and Anatomy, Ribeirão Preto Faculty of Medicine, University of São Paulo, Brazil. 